\title{
REKONFIGURASI JARINGAN DISTRIBUSI \\ UNTUK MEMINIMISASI RUGI-RUGI PADA PENYULANG KABUT DI GARDU INDUK TELUK BETUNG MENGGUNAKAN METODE BINARY PARTICLE SWARM OPTIMIZATION (BPSO)
}

\author{
Osea Zebua $^{1^{*}}$, I Made Ginarsa ${ }^{2}$ \\ ${ }^{1}$ Jurusan Teknik Elektro, Universitas Lampung \\ 2 Jurusan Teknik Elektro, Universitas Mataram \\ *Corresponding author, e-mail : oseaz89@yahoo.com
}

\begin{abstract}
Abstrak-Rekonfigurasi jaringan distribusi sangat diperlukan untuk mengurangi rugi-rugi khususnya pada daerah yang berpenduduk padat. Berbagai metode dan teknik rekonfigurasi telah diusulkan untuk tujuan meminimalkan rugi-rugi daya. Makalah ini menyajikan rekonfigurasi jaringan distribusi dengan menggunakan metode binary particle swarm optimization (BPSO) dengan studi kasus penyulang Kabut di gardu induk Teluk Betung. Rekonfigurasi dilakukan hanya dengan membuat saluran baru tanpa merubah jumlah saluran. Hasil penelitian menunjukkan bahwa dengan merencanakan empat saluran baru, metode BPSO dapat menemukan konfigurasi baru yang lebih meminimalkan rugi-rugi. Rugi-rugi daya aktif yang dihasilkan dari konfigurasi baru sebesar $47,1043 \mathrm{~kW}$ atau berkurang sebesar 1,81\% dari rugi-rugi daya aktif sebelum rekonfigurasi, yakni 47,9477 kW. Profil tegangan pada setiap bus juga lebih baik dari tegangan sebelum rekonfigurasi, dimana tegangan minimum yang diperoleh adalah sebesar 0,98603 per unit dibandingkan dengan tegangan minimum 0,98597 per unit sebelum rekonfigurasi. Namun pemilihan posisi awal terbaik dari seluruh kumpulan partikel di luar lup konfigurasi yang dibentuk oleh saluran baru dapat menyebabkan kegagalan untuk menemukan konfigurasi terbaik.
\end{abstract}

Kata Kunci : Rekonfigurasi, jaringan distribusi, minimisasi rugi-rugi, BPSO, penyulang

\begin{abstract}
Distribution network reconfiguration is needed to minimize losses, especially in densely populated areas. Various reconfiguration methods and techniques have been proposed for the purpose of minimizing power losses. This paper presents a reconfiguration of the distribution network using the binary particle swarm optimization (BPSO) with a case study in Kabut feeder at the Teluk Betung substation. Reconfiguration is performed only by creating new lines without changing the number of lines. The results showed that with the planned four new lines, BPSO method can find new configuration to further minimizes losses. Active power losses resulting from the new configuration is $47.1043 \mathrm{~kW}$ or decreased by $1.81 \%$ of active power losses before the reconfiguration, i.e. $47.9477 \mathrm{~kW}$. Voltage profile on each bus is better than those of before reconfiguration, where the minimum voltage obtained is 0.98603 per unit compared with a minimum voltage of 0.98597 per unit prior to reconfiguration. However, the selection of the best initial position of the whole of particle swarms outside loop configuration formed by new lines may cause a failure to find the best configuration.
\end{abstract}

Keywords : Reconfiguration, distribution network, loss minimization, BPSO, feeder

Copyright $@ 2016$ JNTE. All rights reserved

\section{PENDAHULUAN}

Penambahan beban yang diikuti dengan penambahan jaringan baru pada jaringan distribusi daya listrik mengakibatkan rugi-rugi yang terjadi pada saluran distribusi semakin besar. Pada daerah yang berpenduduk padat penambahan jaringan baru biasanya dibatasi oleh beberapa hal, seperti lokasi yang digunakan, sehingga pengurangan rugi-rugi saluran dapat dilakukan dengan memasang peralatan kompensasi daya reaktif ataupun dengan melakukan rekonfigurasi jaringan.

Jaringan distribusi daya listrik biasanya terdiri dari beberapa penyulang (feeder). Setiap penyulang mempunyai saklar penghubung (tieswitch) yang terbuka pada kondisi operasi normal (normally open) untuk memisahkan masing-masing penyulang, serta saklar pemisah (sectionalizing switch) yang tertutup pada 
kondisi operasi normal untuk memisahkan bagian-bagian tertentu pada satu penyulang jika terjadi gangguan ataupun untuk pemeliharaan. Rekonfigurasi jaringan distribusi dilakukan dengan mengubah status atau lokasi penempatan saklar-saklar tersebut, merubah jenis kabel yang digunakan atau merubah struktur jaringan untuk mencapai tujuan yakni pengurangan rugi-rugi total, menyeimbangkan beban, dan menstabilkan tegangan pada kondisi operasi normal. Rekonfigurasi yang dilakukan harus tetap memperhitungkan batasan-batasan operasi seperti batasan tegangan operasi, arus maksimum yang mengalir melalui saluran dan tetap mempertahankan struktur jaringan pada kondisi operasi normal.

Beberapa teknik rekonfigurasi jaringan distribusi telah diusulkan dengan berbagai metode optimisasi, baik dengan metode nonheuristic [1],[2] maupun dengan metode heuristic [3] dan meta-heuristic [4]-[7]. Semua metode rekonfigurasi itu bermanfaat untuk membantu operator tenaga listrik di dalam mengoptimalkan operasi distribusi daya listrik.

Makalah ini mengusulkan rekonfigurasi jaringan distribusi untuk meminimalkan rugirugi dengan menggunakan metode binary particle swarm optimization (BPSO) pada satu penyulang. Rekonfigurasi dilakukan dengan mencoba beberapa hubungan baru antar bus dari konfigurasi yang sudah ada pada jaringan distribusi, tanpa merubah posisi transformator distribusi, jumlah saluran dan struktur jaringan radial. Studi kasus yang digunakan pada rekonfigurasi jaringan distribusi ini adalah penyulang Kabut di Gardu Induk Teluk Betung.

\section{TINJAUAN PUSTAKA}

\subsection{Rekonfigurasi Jaringan Distribusi Radial \\ Rekonfigurasi jaringan distribusi} dilakukan dengan tujuan meminimisasi rugirugi dapat dilakukan dengan berbagai cara, antara lain merubah status saklar pemisah dan saklar penghubung, merubah jenis kabel saluran atau merubah struktur topologi jaringan yang sudah ada.

Penyulang pada jaringan distribusi biasanya mempunyai struktur jaringan radial yang lebih murah biayanya serta lebih mudah dalam pengoperasiannya. Pada jaringan distribusi radial, rugi-rugi total satu penyulang dinyatakan dengan:

$$
P_{\text {totalloss }}=\sum_{i=1}^{n} P_{\text {loss }}(i, i+1)
$$

dimana $P_{\text {loss }}(i, i+1)$ menyatakan rugi-rugi satu bagian saluran yang menghubungkan bus $i$ dan bus $i+1$ dinyatakan dengan:

$$
P_{\text {loss }}(i, i+1)=R_{i} \frac{P_{i}^{2}+Q_{i}^{2}}{\left|V_{i}\right|^{2}}
$$

Rekonfigurasi untuk meminimisasi rugirugi kemudian dapat dirumuskan menjadi:

$$
\min \left(P_{\text {totalloss }}\right)
$$

dengan fungsi batasan:

$$
\begin{aligned}
& V_{i, \text { min }} \leq V_{i} \leq V_{i, \text { max }} \\
& I_{(i, i+1)} \leq I_{(i, i+1) \text { max }}
\end{aligned}
$$

dan harus memenuhi struktur radial.

\subsection{Rekonfigurasi Dengan Metode Binary Particle Swarm Optimization (BPSO) \\ Binary Particle Swarm Optimization} (BPSO) adalah salah satu metode optimisasi berdasarkan konsep kumpulan (swarm) yang cerdas. BPSO merupakan metode optimasi berbasis PSO untuk penyelesaian masalah optimasi secara diskrit [8]. Penyelesaian yang mungkin untuk setiap masalah dapat direpresentasikan dengan suatu partikel. Setiap partikel dalam dimensi ruang pencarian, mempunyai suatu nilai kemampuan yang dievaluasi oleh fungsi kemampuan untuk memilih suatu pengalaman yang baik untuk dirinya sendiri dan kelompok. Kumpulan (swarm) partikel diawali secara acak. Suatu partikel merubah arah pencariannya didasarkan atas dua nilai atau pengalaman pada setiap iterasi. Pertama, pengalaman pencarian yang terbaik dari setiap individu yang disebut dengan pbest. Kedua, hasil yang diperoleh oleh seluruh partikel pada populasi dan disebut gbest. Bila pbest dan gbest diperoleh, partikel memperbaharui kecepatan dan posisinya didasarkan pada: 


$$
\begin{aligned}
& v_{i d}^{\text {new }}=w v_{i d}+c_{i} \times \operatorname{rand}() \times\left(\text { pbest }-x_{i d}\right) \\
& +c_{2} \times \operatorname{rand}() \times\left(\text { gbest }-x_{i d}\right) \\
& x_{i d}^{\text {new }}=x_{i d}+v_{i d}^{\text {new }}
\end{aligned}
$$

dimana $v_{i d}$ adalah kecepatan awal dari partikel ke- $i, v_{i d}^{\text {new }}$ adalah kecepatan baru dari partikel ke- $i$ dalam dimensi ruang pencarian $d, w$ adalah nilai bobot, $c_{1}$ dan $c_{2}$ adalah konstanta percepatan $x_{i d}$ adalah posisi awal dari partikel $i$, $x_{i d}^{\text {new }}$ adalah posisi baru dari partikel $i$ dan $\operatorname{rand}()$ adalah bilangan acak antara 0 dan 1 .

Algoritma BPSO didisain untuk menyelesaikan masalah optimisasi secara kombinasi yang diskrit, dimana partikel mengambil nilai vektor biner dengan panjang $n$ dan kecepatan yang didefinisikan sebagai probabilitas dari bit $x_{n}$ untuk mencapai nilai 1 . BPSO membalikkan rumus untuk kecepatan bila kecepatan dibatasi pada interval $[0,1]$ dengan membatasi fungsi transformasi, yakni, partikel berubah nilainya.

$$
S\left(V_{i d}^{k+1}\right)=\frac{1}{\exp \left(-V_{i d}^{k+1}\right)}
$$

Rumus iterasi untuk posisi partikel adalah sebagai berikut:

$$
x_{i d}^{k+1}=\left\{\begin{array}{l}
1, \text { rand }()<S\left(V_{i d}^{k+1}\right) \\
0, \text { lainnya }
\end{array}\right.
$$

Rekonfigurasi dengan metode BPSO dilakukan dengan menempatkan kumpulan partikel pada saluran-saluran antar bus, yang merupakan representasi rugi-rugi sesuai persamaan 1. Fungsi fitness merupakan fungsi objektif yang harus dicapai dan merupakan penjumlahan total dari rugi-rugi yang terdapat pada saluran. Hasil akhir yang terbaik dari seluruh partikel merupakan penyelesaian optimisasi dengan fungsi fitness yang paling minimum, dan memberikan informasi tentang lokasi terbaik dari saluran yang harus diputus.

Beberapa metode rekonfigurasi jaringan distribusi menggunakan metode BPSO telah dilakukan untuk kebutuhan menyeimbangkan beban [9] dan meminimisasi rugi-rugi dengan teknik yang berbeda [10]-[11].

\section{METODOLOGI PENELITIAN}

\subsection{Pemodelan jaringan distribusi}

Jaringan distribusi dimodelkan dengan model bus, saluran dan beban. Bus pada jaringan distribusi merepresentasikan transformator distribusi. Model saluran menyatakan besaran resistansi dan reaktansi kabel antara bus dalam per unit. Model beban dinyatakan dalam daya aktif dan daya reaktif. Pemodelan dilakukan dengan studi kasus

\begin{tabular}{|c|c|c|c|}
\hline \multirow{2}{*}{ No. Bus } & \multirow{2}{*}{ Nema Bus } & \multicolumn{2}{|c|}{ Beban Ekivalen } \\
\hline & & $\begin{array}{c}\text { Daya Aktif P } \\
\text { (kW) }\end{array}$ & $\begin{array}{c}\text { Daya Reaktif } \\
\text { Q (kVAR) }\end{array}$ \\
\hline 1 & $\begin{array}{l}\text { GI Teluk } \\
\text { Betung }\end{array}$ & - & - \\
\hline 2 & $\mathrm{~K} 30$ & 311,33 & 192,88 \\
\hline 3 & K626 & 121,35 & 75,18 \\
\hline 4 & $\mathrm{~K} 724$ & 121,35 & 75,18 \\
\hline 5 & K260 & 161,36 & 99,97 \\
\hline 6 & K13 & 85,78 & 53,14 \\
\hline 7 & $\mathrm{~K} 720$ & 61,44 & 38,06 \\
\hline 8 & $\mathrm{~K} 113$ & 124,26 & 76,98 \\
\hline 9 & $\mathrm{~K} 211$ & 148,79 & 92,18 \\
\hline 10 & $\mathrm{~K} 476$ & 61,25 & 37,94 \\
\hline 11 & $\mathrm{~K} 690$ & 44,17 & 27,36 \\
\hline 12 & K41 & 169,60 & 105,07 \\
\hline 13 & K689 & 55,95 & 34,66 \\
\hline 14 & K110 & 87,16 & 54,00 \\
\hline 15 & $\mathrm{~K} 69$ & 117,39 & 72,72 \\
\hline 16 & K76 & 47,70 & 29,55 \\
\hline 17 & K328 & 123,67 & 76,62 \\
\hline 18 & K.761 & 75,83 & 46,98 \\
\hline 19 & K 762 & 151,68 & 93,97 \\
\hline 20 & K537 & 133.48 & 82,70 \\
\hline 21 & K86 & 56,93 & 35,27 \\
\hline 22 & K137 & 66,55 & 41,23 \\
\hline 23 & K195 & 155,08 & 96,07 \\
\hline 24 & K157 & 303,37 & 187,94 \\
\hline 25 & $\mathrm{~K} 207 \mathrm{~B}$ & 97,56 & 60,44 \\
\hline 26 & $\mathrm{~K} 248$ & 63,40 & 39,28 \\
\hline 27 & $\mathrm{~K} 45$ & 159,59 & 98,87 \\
\hline 28 & K60 & 213,73 & 132,44 \\
\hline 29 & $\mathrm{~K} 669$ & 110,12 & 68,22 \\
\hline 30 & K.218 & 101,68 & 63,00 \\
\hline 31 & K58 & 152,92 & 94,74 \\
\hline 32 & K 759 & 75,83 & 46,98 \\
\hline 33 & $\mathrm{~K} 472$ & 21,40 & 13,26 \\
\hline 34 & K.647 & 88,33 & 54,73 \\
\hline 35 & $\mathrm{~K} 721$ & 75,77 & 46,94 \\
\hline 36 & K 767 & 75,83 & 46,98 \\
\hline 37 & K19 & 178,44 & 110,55 \\
\hline 38 & K107 & 151,54 & 93,89 \\
\hline 39 & $\mathrm{~K} 712$ & 121,35 & 75,18 \\
\hline 40 & K180 & 263,83 & 163,45 \\
\hline 41 & $\mathrm{~K} 327$ & 75,83 & 46,98 \\
\hline 42 & K597 & 75,83 & 46,98 \\
\hline 43 & $\mathrm{~K} 725$ & 151,68 & 93,97 \\
\hline 44 & K36 & 168,82 & 104,59 \\
\hline 45 & K703 & 49,27 & 30,52 \\
\hline 46 & K613 & 151,68 & 93,97 \\
\hline
\end{tabular}
jaringan distribusi penyulang Kabut di Gardu Induk Teluk Betung dengan menggunakan datadata hasil pengukuran [12].

Tabel 1. Data Bus dan Beban Penyulang Kabut 
Jaringan distribusi penyulang Kabut mempunyai 46 transformator distribusi atau bus, dengan beban maksimum pada masingmasing bus ditunjukkan pada Tabel 1. Jaringan distribusi penyulang Kabut juga mempunyai 45 saluran yang menghubungkan antar bus dengan besar resistansi dan reaktansi masing-masing saluran dinyatakan dalam per unit dengan basis daya 100 MVA dan basis tegangan $20 \mathrm{kV}$ seperti ditunjukkan pada Tabel 2. Hampir keseluruhan saluran pada penyulang Kabut adalah saluran udara menggunakan kabel jenis AAAC berdiameter $150 \mathrm{~mm}^{2}$, dengan resistansi $0,2162 \mathrm{ohm} / \mathrm{km}$ dan reaktansi $0,3305 \mathrm{ohm} / \mathrm{km}$.

Tabel 2. Data Saluran Penyulang Kabut

\begin{tabular}{|c|c|c|c|c|c|c|}
\hline \multirow{2}{*}{ No } & \multirow{2}{*}{$\begin{array}{l}\text { Dari } \\
\text { Bus }\end{array}$} & \multirow{2}{*}{$\begin{array}{l}\mathrm{Ke} \\
\text { Bus }\end{array}$} & \multicolumn{2}{|c|}{$\begin{array}{l}\text { Nilai Impedansi } \\
\text { Saluran (ohm) }\end{array}$} & \multicolumn{2}{|c|}{$\begin{array}{l}\text { Nilai Impedansī } \\
\text { Saluran (pu) }\end{array}$} \\
\hline & & & $\mathrm{R}$ & $\mathrm{x}$ & $\mathrm{R}$ & $\mathrm{x}$ \\
\hline 1 & 1 & 2 & 0,3913 & 0,5982 & 0,0978 & 0,1496 \\
\hline 2 & 2 & 3 & 0,0002 & 0,0003 & 0,0001 & 0,0001 \\
\hline 3 & 3 & 4 & 0,0448 & 0,0684 & 0,0112 & 0,0171 \\
\hline 4 & 4 & 5 & 0,0026 & 0,0040 & 0,0006 & 0,0010 \\
\hline 5 & 5 & 6 & 0,0566 & 0,0866 & 0,0142 & 0,0216 \\
\hline 6 & 6 & 7 & 0,0199 & 0,0304 & 0,0050 & 0,0076 \\
\hline 7 & 7 & 8 & 0,0147 & 0,0225 & 0,0037 & 0,0056 \\
\hline 8 & 8 & 9 & 0,0166 & 0,0254 & 0,0042 & 0,0064 \\
\hline 9 & 9 & 10 & 0,0534 & 0,0078 & 0,0134 & 0,0020 \\
\hline 10 & 10 & 11 & 0,0158 & 0,0241 & 0,0039 & 0,0060 \\
\hline 11 & 11 & 12 & 0,0290 & 0,0443 & 0,0072 & 0,0111 \\
\hline 12 & 12 & 13 & 0,0154 & 0,0235 & 0,0038 & 0,0059 \\
\hline 13 & 13 & 14 & 0,0039 & 0,0059 & 0,0010 & 0,0015 \\
\hline 14 & 14 & 15 & 0,0227 & 0,0347 & 0,0057 & 0,0087 \\
\hline 15 & 13 & 16 & 0,0186 & 0,0284 & 0,0046 & 0,0071 \\
\hline 16 & 13 & 17 & 0,0445 & 0,0681 & 0,0111 & 0,0170 \\
\hline 17 & 17 & 18 & 0,0002 & 0,0003 & 0,0001 & 0,0001 \\
\hline 18 & 18 & 19 & 0,0445 & 0,0681 & 0,0111 & 0,0170 \\
\hline 19 & 14 & 20 & 0,0103 & 0,0051 & 0,0026 & 0,0013 \\
\hline 20 & 15 & 21 & 0,0158 & 0,0241 & 0,0039 & 0,0060 \\
\hline 21 & 15 & 22 & 0,0435 & 0,0664 & 0,0109 & 0,0166 \\
\hline 22 & 22 & 23 & 0,0613 & 0,0475 & 0,0153 & 0,0119 \\
\hline 23 & 3 & 24 & 0,0279 & 0,0426 & 0,0070 & 0,0107 \\
\hline 24 & 4 & 25 & 0,0372 & 0,0568 & 0,0093 & 0,0142 \\
\hline 25 & 4 & 26 & 0,0627 & 0,0958 & 0,0157 & 0,0240 \\
\hline 26 & 26 & 27 & 0,0454 & 0,0694 & 0,0114 & 0,0174 \\
\hline 27 & 27 & 28 & 0,0975 & 0,1491 & 0,0244 & 0,0373 \\
\hline 28 & 26 & 29 & 0,0281 & 0,0430 & 0,0070 & 0,0107 \\
\hline 29 & 5 & 30 & 0,0422 & 0,0644 & 0,0105 & 0,0161 \\
\hline 30 & 30 & 31 & 0,0448 & 0,0684 & 0,0112 & 0,0171 \\
\hline 31 & 31 & 32 & 0,0448 & 0,0684 & 0,0112 & 0,0171 \\
\hline 32 & 30 & 33 & 0,0279 & 0,0426 & 0,0070 & 0,0107 \\
\hline 33 & 31 & 34 & 0,0104 & 0,0159 & 0,0026 & 0,0040 \\
\hline 34 & 34 & 35 & 0,0283 & 0,0432 & 0,0071 & 0,0108 \\
\hline 35 & 35 & 36 & 0,0283 & 0,0432 & 0,0071 & 0,0108 \\
\hline 36 & 36 & 37 & 0,0281 & 0,0430 & 0,0070 & 0,0107 \\
\hline 37 & 35 & 38 & 0,1055 & 0,0818 & 0,0264 & 0,0204 \\
\hline 38 & 38 & 39 & 0,0332 & 0,0257 & 0,0083 & 0,0064 \\
\hline 39 & 39 & 40 & 0,0156 & 0,0238 & 0,0039 & 0,0059 \\
\hline 40 & 40 & 41 & 0,0117 & 0,0178 & 0,0029 & 0,0045 \\
\hline 41 & 41 & 42 & 0,0255 & 0,0390 & 0,0064 & 0,0097 \\
\hline 42 & 40 & 43 & 0,0117 & 0,0178 & 0,0029 & 0,0045 \\
\hline 43 & 6 & 44 & 0,0595 & 0,0909 & 0,0149 & 0,0227 \\
\hline 44 & 44 & 45 & 0,0226 & 0,0345 & 0,0056 & 0,0086 \\
\hline 45 & 8 & 46 & 0,0013 & 0,0020 & 0,0003 & 0,0005 \\
\hline
\end{tabular}

\subsection{Simulasi rekonfigurasi jaringan distribusi dengan metode BPSO.}

Simulasi dilakukan dengan skenario penambahan saluran baru pada jaringan yang sudah ada. Saklar penghubung yang terbuka pada operasi normal digunakan sebagai representasi saluran yang terputus atau terbuka. Hasil penempatan optimal dari saklar penghubung yang menghasilkan rugi-rugi minimum merepresentasikan saluran yang harus diputus untuk menghasilkan konfigurasi baru. Jumlah saluran baru yang direncanakan merupakan dimensi ruang pencarian untuk metode BPSO.

Prosedur simulasi rekonfigurasi jaringan distribusi penyulang Kabut menggunakan metode BPSO diringkaskan sebagai berikut:

1. Masukkan data jaringan distribusi dan rencana jaringan baru.

2. Inisialisasi parameter dan posisi awal kumpulan populasi (swarm), yakni jumlah partikel pada setiap kumpulan, posisi awal setiap partikel dari kumpulan secara acak, pbest dan posisi awal terbaik dari kumpulan secara keseluruhan, gbest dalam dimensi pencarian.

3. Evaluasi fungsi fitness awal pada iterasi $k=1$.

4. Hitung kecepatan dan posisi partikel, $v_{i d}^{k}$ dan $x_{i d}^{k}$.

5. Evaluasi fungsi fitness setiap partikel, pbest.

6. Periksa struktur radial.

7. Update kecepatan dan posisi terbaik, $v_{i d}^{\text {new }}$ dan $x_{i d}^{\text {new }}$.

8. Evaluasi ulang fungsi fitness setiap partikel, pbest dan evaluasi fungsi fitness keseluruhan, gbest.

9. Periksa apakah konstrain dipenuhi. Jika ya, maka hasil disimpan.

10.Update gbest jika konstrain tidak dipenuhi atau jika konstrain dipenuhi dan hasil telah disimpan.

11.Ulangi langkah $d$ jika iterasi belum mencapai nilai iterasi maksimum. Jika iterasi lebih besar dari nilai iterasi maksimum, maka tampilkan hasil.

Simulasi rekonfigurasi jaringan distribusi penyulang Kabut dilakukan dengan menggunakan perangkat lunak MATLAB [13], dengan program perhitungan aliran daya dan 
rugi-rugi menggunakan perangkat lunak Matpower [14]. Bagan alir pemrograman ditunjukkan pada Gambar 1.

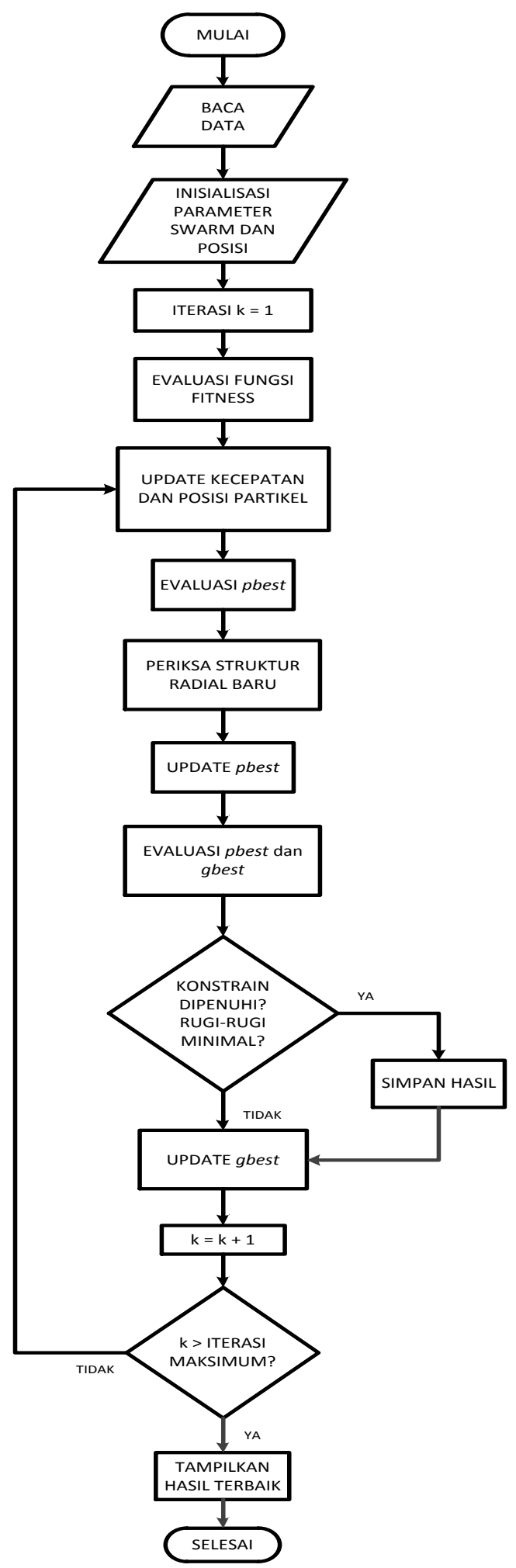

Gambar 1. Diagram Bagan Alir Pemrograman

\section{HASIL DAN PEMBAHASAN}

Diagram satu garis penyulang Kabut ditunjukkan pada Gambar 2. Garis putus-putus pada gambar 2 menyatakan konfigurasi rancangan baru, sedangkan garis melingkar terputus menunjukkan lup yang dibentuk oleh masing-masing saluran baru.

Rugi-rugi hasil perhitungan aliran daya untuk penyulang Kabut sebelum rekonfigurasi adalah rugi-rugi daya aktif sebesar 47,9477 kW dan rugi-rugi daya reaktif $72,594 \mathrm{kVAR}$. Tegangan minimum dari bus-bus di penyulang Kabut ini adalah 0,98597 p.u atau sekitar $19,7194 \mathrm{kV}$.

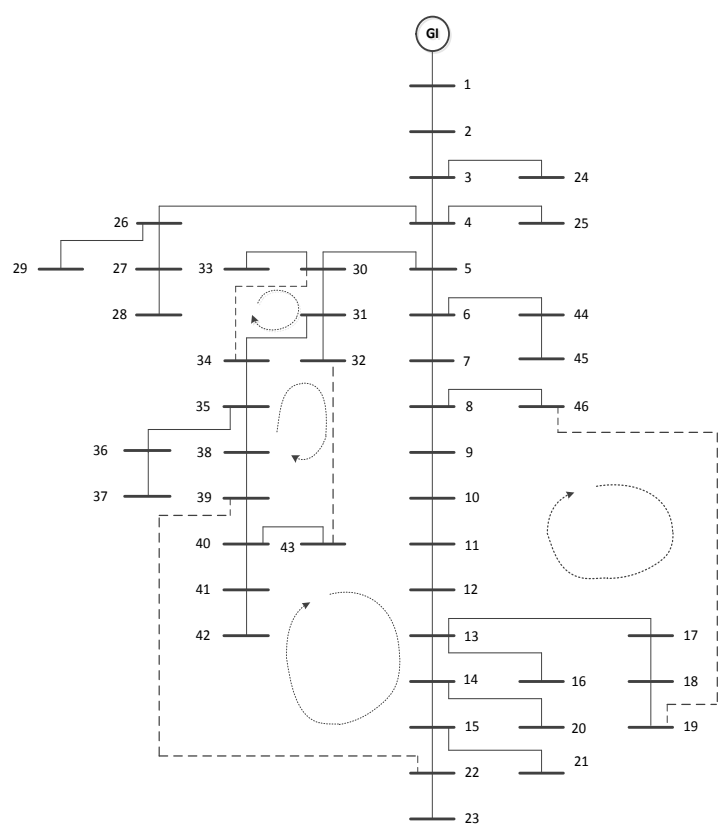

Gambar 2. Diagram Satu Garis Penyulang Kabut

Proses rekonfigurasi dilakukan dengan menambahkan empat saluran baru pada jaringan yang sudah ada, yakni dengan menghubungkan bus 19 dan bus 46, bus 22 dan bus 39 , bus 30 dan bus 34 serta bus 32 dan bus 43.

Tabel 3. Data Rencana Saluran Baru

\begin{tabular}{|c|c|c|c|c|c|}
\hline $\begin{array}{c}\text { Nomor } \\
\text { saluran }\end{array}$ & $\begin{array}{c}\text { Dari } \\
\text { bus }\end{array}$ & $\begin{array}{c}\text { Ke } \\
\text { bus }\end{array}$ & $\begin{array}{c}\text { Panjang } \\
(\mathrm{km})\end{array}$ & $\begin{array}{c}\text { Resistansi } \\
(\mathrm{pu})\end{array}$ & $\begin{array}{c}\text { Reaktansi } \\
(\mathrm{pu})\end{array}$ \\
\hline 46 & 19 & 46 & 0,085 & 0,0046 & 0,0070 \\
\hline 47 & 22 & 39 & 0,083 & 0,0045 & 0,0069 \\
\hline 48 & 30 & 34 & 0,1 & 0,0054 & 0,0083 \\
\hline 49 & 32 & 43 & 0,09 & 0,0049 & 0,0074 \\
\hline
\end{tabular}


Pertimbangan yang digunakan dalam pemilihan saluran baru adalah saluran harus mempunyai jalur yang menghubungkan busbus yang berdekatan dengan jalur yang tidak berada di atas perumahan. serta menggunakan jenis kabel yang sama Data rencana saluran baru ditunjukkan pada Tabel 3.

Simulasi dilakukan dengan jumlah partikel 20 dan posisi awal setiap partikel ditentukan secara acak. Nilai awal dari posisi terbaik secara keseluruhan gbest ditentukan dengan memilih saluran yang terdapat pada lup yang dibentuk oleh saluran baru. Dari 100 kali percobaan simulasi dan iterasi maksimum 50 diperoleh hasil seperti yang ditunjukkan pada Tabel 4.

Tabel 4. Hasil Simulasi Rekonfigurasi Penyulang Kabut Dengan Metode BPSO

\begin{tabular}{|c|c|c|}
\hline & $\begin{array}{c}\text { Sebelum } \\
\text { Rekonfigurasi }\end{array}$ & $\begin{array}{c}\text { Setelah } \\
\text { Rekonfigurasi }\end{array}$ \\
\hline $\begin{array}{c}\text { Posisi saklar } \\
\text { penghubung } \\
\text { pada saluran }\end{array}$ & $46,47,48,49$ & $12,33,39,47$ \\
\hline $\begin{array}{c}\text { Rugi-rugi daya } \\
\text { aktif }\end{array}$ & $47,9477 \mathrm{~kW}$ & $47,1043 \mathrm{~kW}$ \\
\hline $\begin{array}{c}\text { Pengurangan } \\
\text { rugi-rugi daya } \\
\text { aktif }\end{array}$ & - & $1,759 \%$ \\
\hline $\begin{array}{c}\text { Tegangan } \\
\text { minimum }\end{array}$ & $0,98597 \mathrm{pu}$ & $0,98603 \mathrm{pu}$ \\
\hline
\end{tabular}

Dari hasil simulasi dengan metode BPSO diperoleh konfigurasi radial baru dari sistem distribusi penyulang Kabut yang dapat mengurangi rugi-rugi secara optimal, yakni dengan rugi-rugi daya aktif $47,104 \mathrm{~kW}$ atau berkurang $1,759 \%$, dan rugi-rugi daya reaktif 71,969 kVAR. Konfigurasi baru yang diperoleh merupakan konfigurasi radial dengan jumlah saluran yang harus diputus sama dengan jumlah hubungan baru yang direncanakan. Hasil rekonfigurasi dinyatakan dengan nomor saluran dimana saklar penghubung harus ditempatkan, artinya saluran yang menghubungkan bus 12 dan bus 13, bus 31 dan bus 34 serta bus 39 dan bus 40 dari konfigurasi sebelumnya harus diputus. Sementara saluran baru yang menghubungkan bus 19 dan 46 , bus 30 dan bus 34 serta bus 32 dan bus 43 harus dibuat. Rencana saluran yang menghubungkan bus 22 dan bus 39 tidak meminimalkan rugi-rugi, dan hasil simulasi dengan metode BPSO menunjukkan bahwa saklar pemisah ditempatkan pada saluran yang menghubungkan bus 22 dan bus 39 ini, yang artinya saluran yang menghubungkan kedua bus ini harus diputus. Hasil rekonfigurasi ditunjukkan dengan diagram satu garis pada Gambar 3.

Hasil rekonfigurasi juga memperbaiki profil tegangan pada beberapa bus pada penyulang Kabut, dimana perbandingan nilai tegangan setiap bus sebelum dan sesudah rekonfigurasi ditunjukkan pada Gambar 4.

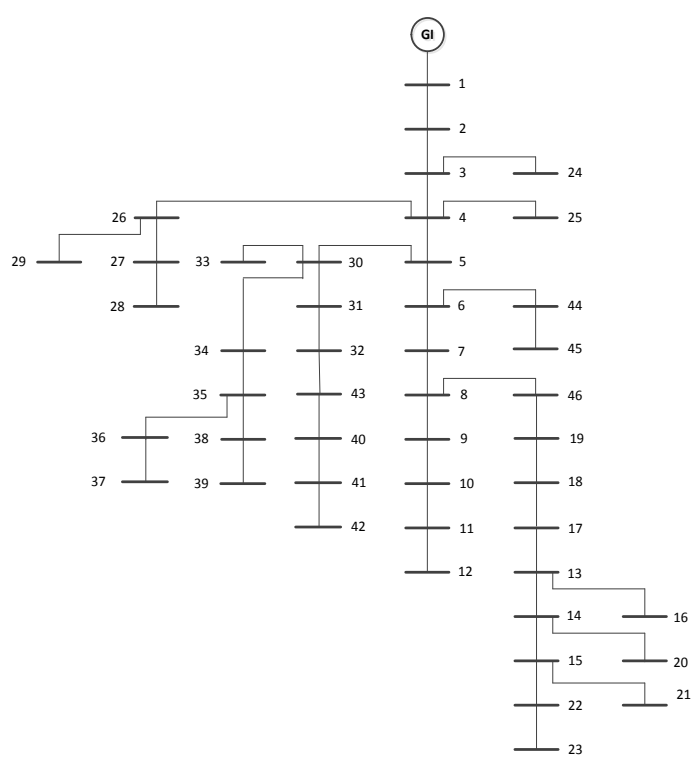

Gambar 3. Hasil Rekonfigurasi Jaringan

Distribusi Penyulang Kabut

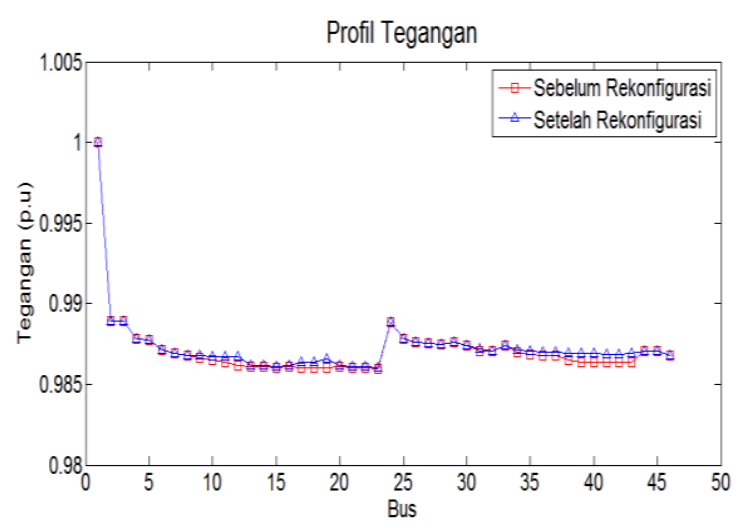

Gambar 4. Profil Tegangan Pada Setiap Bus Pada Penyulang Kabut

Saluran yang diputus dari konfigurasi sebelumnya masing-masing mempunyai panjang, $0,071 \mathrm{~km}$ untuk saluran yang menghubungkan bus 12 dan bus 13, 0,048 km untuk saluran yang menghubungkan bus 31 dan bus 34 dan $0,072 \mathrm{~km}$ untuk saluran yang 
menghubungkan bus 39 dan bus 40. Ketiga saluran ini lebih pendek dari saluran baru pengganti seperti yang ditunjukkan pada tabel 3 , namun rugi-rugi dapat lebih diminimalkan dan profil tegangan pada beberapa bus juga lebih baik dengan konfigurasi yang baru. Ditinjau dari sisi ekonomis, konfigurasi baru sedikit lebih mahal dari konfigurasi sebelumnya, namun dalam jangka panjang kerugian ekonomis akibat rugi-rugi menjadi perhatian yang lebih penting. Selain itu, profil tegangan pada kondisi operasi menjadi lebih baik.

Pengujian dengan menambah jumlah iterasi dan jumlah partikel tidak merubah hasil simulasi rekonfigurasi. Pengujian harus dilakukan berulang kali karena metode BPSO merupakan metode optimisasi stokastik. Pemilihan posisi awal terbaik dari keseluruhan kumpulan partikel (gbest) di luar lup yang dibentuk oleh skema hubungan baru yang direncanakan dapat menyebabkan hasil simulasi rekonfigurasi yang kurang baik dan bahkan gagal.

Keuntungan dari rekonfigurasi jaringan distribusi menggunakan metode BPSO adalah rekonfigurasi dapat dilakukan dengan jumlah rencana saluran baru yang bervariasi tergantung pada kemungkinan saluran baru yang memenuhi kebutuhan perencanaan dan kondisi standar penambahan jaringan, seperti tidak melewati perumahan dan lain-lain.

\section{KESIMPULAN}

1. Rekonfigurasi saluran distribusi pada penyulang Kabut di gardu induk Teluk Betung menggunakan metode BPSO dapat meminimalkan rugi-rugi yang dihasilkan sekaligus memperbaiki profil tegangan pada beberapa bus. Hasil simulasi menunjukkan pengurangan rugi-rugi total daya aktif yang dihasilkan sebesar 47,1043 $\mathrm{kW}$ atau 1,759\% dibandingkan rugi-rugi daya aktif sebesar 47,9477 kW sebelum rekonfigurasi. Profil tegangan pada setiap bus di penyulang Kabut diperbaiki dengan tegangan minimum menjadi 0,98603 per unit dibandingkan 0,98597 per unit sebelum rekonfigurasi.

2. Pemilihan posisi awal terbaik dari keseluruhan kumpulan sangat mempengaruhi keberhasilan metode BPSO untuk memperoleh konfigurasi terbaik.

\section{DAFTAR PUSTAKA}

[1]. Civanlar, S., Grainger J.J., Yin, H. and Lee, S., Distribution Feeder Reconfiguration for Loss Reduction, IEEE Trans. on Power Delivery, vol. 3, no. 3, pp.1217-1223 (1988).

[2]. Baran, M.E. and Wu, F.F., Network Reconfiguration in Distribution System for Loss Reduction and Load Balancing, IEEE Trans. on Power Delivery, vol.4, no.2, pp.1401-1407 (1989).

[3]. Wagner, T.P., Chikhani, A.Y., and Hackam, R., Feeder Reconfiguration for Loss Reduction: An Application of Distribution Automation, IEEE Trans. on Power Delivery, vol.6, no.4, pp.19221933 (1991).

[4]. Lin, C.H., Chen, C.S., Wu, C.J., and Kang, M.S., Application of Immune Algorithm to Optimal Switching Operation for Distribution Loss Minimisation and Loading Balance, IEE Proc. Generation, Transmission and Distribution, vol.150, no.2, pp.183-189 (2003).

[5]. Salazar, H., Gallego, R., and Romero, R., Artificial Neural Networks and Clustering Techniques Applied in Reconfiguration of Distribution Systems, IEEE Trans. on Power Delivery, vol.21, no.3, pp.1735-1742 (2006).

[6]. Ahuja, A., and Pahwa, A., Using Ant Colony Optimization for Loss Minimization in Distribution Networks, Proc. of $37^{\text {th }}$ Annual North American Power Symposium, pp.470-474 (2005).

[7]. Hsu, F.Y., and Tsai, M.S., A MultiObjective Evolution Programming Method for Feeder Reconfiguration of Power Distribution System, Proc. of the $13^{\text {th }}$ International Conference on Intelligent Systems Application to Power Systems, pp.55-60 (2005).

[8]. Eberhart R.C. and Kennedy J., A Discrete Binary Version of the Particle Swarm Algorithm, Proceedings of IEEE International Conference on Systems, Man, and Cybernetics, vol. 5, pp.41044108 (1997).

[9]. Xiaoling, J., Jianguo, Z., Ying, S., Kejun, L., and Boqin, Z., Distribution Network 
Reconfiguration for Load Balancing Using Binary Particle Swarm Optimization, International Conference on Power System Technology (PowerCon) Volume I, pp.507-510 (2004).

[10]. Wu, W.C., Tsai, M.S., and Hsu, F.Y., A New Binary Coding Particle Swarm Optimization for Feeder Reconfiguration, International Conference on Intelligent Systems Application to Power Systems (ISAP), pp.1-6 (2007).

[11]. Tandon, A., and Saxena, D., Optimal Reconfiguration of Electrical Distribution Network Using Selective Particle Swarm Optimization Algorithm, International Conference on Power, Control and Embedded Systems (ICPCES), pp.1-6 (2014).

[12]. PT. PLN (Persero) UPT Tanjung Karang, .Data Pengukuran Gardu dan Single Line Diagram Penyulang GI Teluk Betung, (2012).

[13]. MATLAB 7.12.0.635 (R2011a) User Guide, www.mathwork.com, (2011).

[14]. Zimmerman, R.D., Murillo-Sanchez, C.E. and Thomas, R.J., Matpower: Steady-State Operations, Planning and Analysis Tools for Power Systems Research and Education, IEEE Trans. on Power Systems, vol.26, no.1, pp.12-19 (2011).

\section{Biodata Penulis}

Osea Zebua, lahir di Medan tanggal 9 Juni 1970. Menamatkan pendidikan S1 di Jurusan Teknik Elektro Universitas Sumatera Utara tahun 1995 dan pendidikan S2 di Jurusan Teknik Elektro Universitas Gadjah Mada tahun 2001.

I Made Ginarsa, lahir di Denpasar tanggal 25 Maret 1970. Menamatkan pendidikan S1 di Jurusan Teknik Elektro Universitas Udayana tahun 1997, pendidikan S2 di Jurusan Teknik Elektro Universitas Gadjah Mada tahun 2001 dan pendidikan S3 di Jurusan Teknik Elektro Institut Teknologi Sepuluh Nopember tahun 2012. 